Kamila Żukowska

Uniwersytet Łódzki

eudajmone@gmail.com

\title{
Utopijne światy Ignacego Krasickiego w kontekście filozofii społecznej oświecenia
}

\author{
The Utopian Worlds of Ignacy Krasicki in the Context of the Social Philosophy \\ of the Enlightenment
}

\begin{abstract}
The essay presents an analysis of the philosophical and anthropological context of the utopia presented by Ignacy Krasicki in his novel Przypadki Mikotaja Doświadczyńskiego (The Adventures of Mr. Nicholas Wisdom). The utopia of Nipu is treated as a literary example of the Enlightenment society, in which there occurs a clash of human values. This conflict resists the irreconcilable, traditional axiology of the author and the Western system social philosophy of the times. That is why Krasicki's utopia constitutes a unique vision of a world which - contrary to the logic of the Enlightenment - cannot be rational and harmonious.
\end{abstract}

Keywords: Ignacy Krasicki, utopia, philosophy, society, Enlightenment, Jean Jacques Rousseau

Streszczenie: Szkic jest analizą kontekstu filozoficzno-antropologicznego utopii przedstawionej przez Ignacego Krasickiego w powieści Przypadki Mikotaja Doświadczyńskiego. Utopia Nipu zostaje potraktowana jako literacka propozycja społeczeństwa oświeceniowego, w której dochodzi do konfliktu podstawowych, ludzkich wartości. Konflikt ten opiera się na niemożliwej do pogodzenia tradycyjnej aksjologii autora i zachodniego systemu ówczesnej filozofii społecznej. Z tego powodu utopia Krasickiego stanowi wyjątkową wizję świata, który wbrew oświeceniowej logice nie może być światem racjonalnym i harmonijnym.

Słowa kluczowe: Ignacy Krasicki, utopia, filozofia, społeczeństwo, oświecenie, Jean Jacques Rousseau

Choć interpretacji utopii przedstawionej w powieści Mikotaja Doświadczyńskiego przypadki Ignacego Krasickiego poświęcono niemało miejsca na kartach historycznoliterackich opracowań, wciąż brak satysfakcjonującej analizy pozaliterackich uwarunkowań owej, bądź co bądź, charakterystycznie 
oświeceniowej wizji racjonalnej struktury społecznej ${ }^{1}$. Toteż w artykule tym stawiam sobie za cel sformułowanie kilku uwag dotyczących powieści o Doświadczyńskim w kontekstach antropologicznym i filozoficznym, pozwalających wkomponować utopię Nipu w szerszy krajobraz uniwersalnej myśli oświeceniowej. Niewątpliwie bowiem, kreśląc w swych utworach dydaktycznych portret współczesnego mu społeczeństwa, Krasicki korzysta z instrumentarium filozoficznego zapożyczonego z kręgów zachodniej refleksji nad ludzką naturą i życiem zbiorowości ${ }^{2}$. Opisana na kartach Mikotaja Doświadczyńskiego przypadków utopia pozostaje zaś pod wyraźnym wpływem osiemnastowiecznych koncepcji natury człowieka i jego roli w społeczeństwie, co zbliża ją do literackiego uniwersum ówczesnej kultury europejskiej, czerpiącej inspirację przede wszystkim z dynamicznych postępów myśli naukowej. Ze względu zaś na nośność i powtarzalność literackich klisz konwencji utopijnej zapoczątkowanej dziełem Thomasa More'a struktura utopii pozwala Krasickiemu na prezentację społeczno-filozoficznej treści w sposób zarazem czytelny i zajmujący dla szerokiego (nie tylko wykształconego) grona ówczesnych czytelników powieści ${ }^{3}$.

$\mathrm{Z}$ racji swego projektującego, konceptualnego charakteru konstrukcja utopijna należy do stałego repertuaru piśmiennictwa filozoficznego ${ }^{4}$. Znana od starożytności w oświeceniu nabiera ona jednak nowego, swoistego znaczenia, stając się nośnikiem częstokroć polemicznych i nowatorskich treści, zogniskowanych wokół zagadnień związanych z teorią państwa i prawa. Casus utopijnej wyspy Nipu, stworzonej przez Krasickiego, nie jest tu wyjątkiem, choć autor wykorzystuje w nim konwencję literacką zapoczątkowaną wraz z Utopia More'a, a nie typowo wykładowy styl utopijnych traktatów społeczno-politycznych (co robi na przykład Jean Jacques Rousseau). W konsekwencji udzielenie trafnej odpowiedzi na najważniejsze pytanie postawione w niniejszym tekście - o teoretyczny fundament kreacji literackiego świata Nipuan zależy od pomyślnego zrekonstruowania głównych założeń oświeceniowego

${ }^{1}$ Na temat utopii w twórczości Krasickiego pisali między innymi: T. Kostkiewiczowa, Polski wiek światet. Obszary swoistości, Wrocław 2002, s. 220-269; taż, Studia o Krasickim, Warszawa 1997; J. Wołoszyński, Ignacy Krasicki: utopia i rzeczywistość, Studia z zakresu Oświecenia, t. 11, Wrocław 1970, a także S. Graciotti, Utopia w dzietach Ignacego Krasickiego, „Przegląd Humanistyczny" 1972, t. 16, nr 4, s. 1-16.

${ }^{2} \mathrm{Na}$ temat zagadnienia wpływu filozofii na literaturę osiemnastowieczną zob. P. Chaunu, Cywilizacja wieku oświecenia, tłum. E. Bąkowska, Warszawa 1989, s. 239.

${ }^{3} \mathrm{Na}$ temat skonwencjonalizowanej struktury utopii podróżniczej i jej podstawowych elementów, do których należą: katastrofa morska bohatera, będąca bezpośrednią przyczyną zetknięcia się z utopijnym społeczeństwem, wykład lokalnego nauczyciela poświęcony zwyczajom panującym w utopijnym społeczeństwie i stosunkowi do cywilizacji europejskiej, zob. B. Baczko, Światta utopii, tłum. W. Dłuski, Warszawa 2016, s. 20, 23 i n.

${ }^{4}$ Zob. na przykład dzieła Thomasa More'a, Francisa Bacona czy Jeana Jacques’a Rousseau. $\mathrm{Na}$ temat utopii w literaturze europejskiej i filozofii pisali między innymi: B. Baczko, dz. cyt. oraz A. Juszczyk, Stary wspaniaty swiat. O utopiach pozytywnych i negatywnych, Kraków 2014. 
państwa i społeczeństwa, wykorzystanych przez autora Mikotaja Doświadczyńskiego przypadków.

Społeczna utopia oświeceniowa, której przedmiotem są teoretyczne podstawy państwotwórczej wspólnoty obywateli, w oczywisty sposób nasuwa skojarzenia z filozoficzno-literacką twórczością Jeana Jacques'a Rousseau 5 . Uchodzący dziś za kontrowersyjnego (z powodu jego postulatów dotyczących wychowania i uproszczonej, najczęściej błędnie odczytywanej koncepcji kontraktualizmu) filozof stworzył teorię umowy społecznej, u której fundamentów legła wolna wola jednostki ${ }^{6}$ - formułując w ten sposób kontrpropozycję względem pesymistycznej wizji świata Thomasa Hobbesa czy liberalnej koncepcji umowy Johna Locke’a. Wśród wprowadzonych przez Rousseau innowacji wyróżnione miejsce zajmuje zwłaszcza wyposażenie człowieka natury $\mathrm{w}$ indywidualne pragnienie, mające wymierny udział $\mathrm{w}$ procesach prowadzących do zawarcia kontraktu. Równie ważnym impulsem w budowie społeczeństwa staje się tu poczucie moralności, które - podobnie jak wolność - stanowi niezbędny element determinujący każdą społeczną umowę 7 . Tylko jednostka pierwotnie wolna, posługująca się rozumem wspartym chęcią stworzenia społeczeństwa opartego na wolnej woli wszystkich jego sygnatariuszy, może zagwarantować państwo pozbawione ucisku ${ }^{8}$. Twór ten stanowi zarazem jedyną pozytywną propozycję w stosunku do pierwotnego stanu natury, w którym człowiek nie poznał jeszcze opresji ze strony instytucji społecznych. Jak bowiem dobitnie pisze Rousseau: zawarcie umowy społecznej dla jednostki oznacza wejście w stan człowieczeństwa ${ }^{9}$. Społeczeństwo skonstruowane zgodnie $\mathrm{z}$ wolną wolą jednostek prowadzi do utożsamienia dobra obywatela z dobrem całej zbiorowości, a co za tym idzie, do wyzbycia się indywidualnych, egoistycznych pobudek ${ }^{10}$. Osiągany w ten sposób stan rzeczy myśliciel wartościuje znacznie wyżej niż samą naturę. Nie jest więc prawdą, jak się powszechnie sądzi, że Rousseau krytykuje każdą formę życia zbiorowego, upatrując rozwiązania generowanych przez nie problemów w powrocie do czasów sprzed rozwoju cywilizacji. Krytykuje on jedynie rządy oparte na hierarchii i niesprawiedliwości, oferując w zamian społeczeństwo powstające za zgodą każdego z jego obywateli, co wyklucza, zdaniem filozofa, możliwość wyzysku i niesprawiedliwości społecznej. Istotą tak rozumianej koncepcji umowy społecznej nie jest więc postulat powrotu do anarchii, a jedynie odnowienie największych wartości społeczeństwa oświeceniowego (równości, wolności i braterstwa). Prawdziwie głęboka odnowa społeczna musi przy tym

${ }^{5} \mathrm{O}$ utopijnych propozycjach Rousseau i oddziaływaniu teorii umowy społecznej na europejską kulturę oświeceniową zob. B. Baczko, dz. cyt.

${ }^{6}$ E. Cassirer, Filozofia oświecenia, tłum. T. Zatorski, Warszawa 2010, s. 239.

7 J.J. Rousseau, Umowa spoteczna, tłum. A. Peretiatkowicz, Kęty 2009, s. 22.

8 E. Cassirer, dz. cyt., s. 239.

9 J.J. Rousseau, dz. cyt., s. 23.

10 E. Cassirer, dz. cyt., s. 240. 
objąć także religijność, której znaturalizowanie powinno dopełnić oświeceniową rewizję chrześcijaństwa, utożsamianego ze zdegenerowaną wersją religii pierwotnej - opartej na pozytywnie wartościowanej tolerancji ${ }^{11}$. Charakter religii naturalnej zniechęca do aktów przemocy wobec wyznawców innych wierzeń, staje się ona tym samym sztandarowym remedium oświeconej Europy na koszmar wojen wyznaniowych, wstrząsających nieustannie dwoma pierwszymi stuleciami nowożytności ${ }^{12}$.

Czas powstania powieści Krasickiego o awanturach Doświadczyńskiego zbiegł się z ujawnieniem autorstwa Rousseau Uwag o rządzie polskim (1774) przez jednego z członków konfederacji barskiej, Michała Wielhorskiego ${ }^{13}$. Duża popularność w Polsce teorii Rousseau zawartych w Emilu, Umowie spotecznej czy Nowej Heloizie zwiększyła się jeszcze za sprawą wykorzystania przez zwolenników wielu opcji politycznych potencjału nowego pisma filozofa traktującego o ustroju Rzeczypospolitej. Co ciekawe, retoryczna siła Uwag o rzadzie polskim służyła zarówno przeciwnikom, jak i zwolennikom panowania Stanisława Augusta ${ }^{14}$. Symptomatyczne jednak, że niezależnie od politycznego stanowiska zręcznie pomijano wątek równości społecznej wszystkich stanów, które podkreślał w swych pismach Rousseau ${ }^{15}$. Krasicki zarówno na łamach Monitora, jak i w prywatnej korespondencji wielokrotnie odnosił się do tez zaproponowanych przez Rousseau, żywo komentując jednak brak pragmatycznego potencjału owych teorii i nadmierny idealizm filozofa z Genewy ${ }^{16}$. Nie był więc pisarz bezkrytycznym zwolennikiem idei wspólnoty opartej na stanie natury. W Mikotaja Doświadczyńskiego przypadkach, jak zauważył Aleksandr Lipatow, Krasicki również wprost parodiuje model wychowania Rousseau, tworząc postać francuskiego, afektowanego guwernera ${ }^{17}$, z kolei problematyka umowy społecznej oraz religii naturalnej to węzłowe zagadnienia utopijnej osnowy wyspy $\mathrm{Nipu}^{18}$. W uwypukleniu ich wagi powinna pomóc uważna analiza szczegółów konstrukcyjnych tej literackiej wizji.

11 Tamże, s. 155.

12 Ekumeniczny charakter religii naturalnej wynika według encyklopedystów (Denisa Diderota) ze zbliżania do siebie wyznawców różnych wyznań. Integralną częścią jej systemu jest bowiem tolerancja. Zob. tamże.

13 A.W. Lipatow, Rousseau i Krasicki: utopia i antyutopia w „Mikotaja Doświadczyńskiego przypadkach”, tłum. Z. Smolska, „Pamiętnik Literacki” 1980, z. 2, s. 67-69.

14 Tamże, s. 67-68.

15 Tamże, s. 69.

16 Tamże, s. 76.

17 Zob. I. Krasicki, Mikotaja Doświadczyńskiego przypadki, oprac. M. Klimowicz, Wroctaw 1975, s. 20-24.

18 Dla Aleksandra Lipatowa ustrój Nipuan to ilustracja tez na temat idealnego społeczeństwa z Umowy spotecznej Rousseau. Autor zwraca uwagę na krytyczny stosunek Krasickiego publicysty do tez Rousseau, w tym przede wszystkim jego koncepcji wychowania zaprezentowanej w Emilu. Według Lipatowa wyspa Nipu, skonstruowana na wzór utopii Rousseau, dla Krasickiego jest raczej antyutopią (dzisiejsza terminologia nadałaby jej raczej miano dystopii) 
Warto też zaznaczyć, że Krasicki jest świadom nikłego realnego oddziaływania aksjologii oświeceniowej na praktykę budowy państwa (jako gwaranta podstawowych praw jednostki ${ }^{19}$ ). Niemniej ulega on pokusie tworzenia literackiego świata idealnego społeczeństwa Nipu, czyniąc przy tym zadość kolejnej oświeceniowej modzie - na dydaktyczną utopię - konwencję rzadko ówcześnie praktykowaną w literaturze polskiej ${ }^{20}$. W dobie renesansu elementy utopii wykorzystywano przede wszystkim w kreacji życia ziemiańskiego (podobnie zresztą czyni sam Krasicki w Panu Podstolim porównywanym z Żywotem cztowieka poczciwego Mikołaja Reja ${ }^{21}$. Wybory tematyczne autorów staropolskich, zainteresowanych jednostką co najwyżej w skali lokalnej i nieodczuwających potrzeby snucia holistycznych projektów społeczeństwa idealnego, nie sprzyjały więc rozwojowi rodzimej konwencji utopijnej. Tymczasem Krasicki, tworząc strukturę społeczną Nipuan, konstruuje swoistą arkadię, której społeczność, choć złożona z poszczególnych jednostek, połączona jest jednak określoną wizją obywatelskiej zbiorowości. Jej fundament stanowią porządek naturalny, równość wszystkich obywateli wobec prawa i działanie zgodnie z imperatywem rozumu - wątki wskazujące na inspiracje zarówno koncepcją umowy społecznej Rousseau, jak i stanowiskiem Kartezjusza, uważającego rozum i naturę za dowody na istnienie Boga ${ }^{22}$. Jak tłumaczy Doświadczyńskiemu Xaoo:

My nie znamy tego, co wy nazywacie monarchią, arystokracją, demokracją, oligarchią etc. W zgromadzeniu naszym nie masz żadnej innej zwierzchności politycznej prócz naturalnej rodziców nad dziećmi. Okoliczności wychodzące nad zamiar szczególnych familii ugodnymi sposoby - radą, nie przemocą - przez starszych uspokojone i rozrządzone bywają. Człowiek jednakowo z drugim człowiekiem rodzący się nie może, a przynajmniej nie powinien by sobie przywłaszczać

i stanowi dlań świadectwo nieprzydatności teorii Rousseau w ówczesnej, realnej polityce europejskiej. Niemniej jednak utopia Nipu jest polemiczną odpowiedzią Krasickiego na ówczesną popularność w Rzeczypospolitej rozważań filozofa z Genewy. Zob. A. Lipatow, dz. cyt., s. 84.

19 Praw tych Oświecenie encyklopedystów poszukuje w samej naturze podmiotu, który od zawsze je posiada i które nie zmieniają się po stworzeniu społeczeństwa opartego na umowie społecznej. Zob. E. Cassirer, dz. cyt., s. 37. Tego rodzaju konstatacja eliminuje paradoks tych koncepcji umowy społecznej, które zakładają nabycie przez podmiot jakichkolwiek praw dopiero w momencie przystąpienia do kontraktu. Okazuje się bowiem, że nie jest możliwe zawarcie umowy przez kogoś, kto nie ma żadnych praw. Na temat paradoksów oświeceniowych koncepcji umów społecznych zob. C. Pateman, Kontrakt ptci, tłum. J. Mikos, Warszawa 2014.

${ }^{20} \mathrm{O}$ utopii w literaturze doby staropolskiej: A. Krzewińska, Początki utopii w literaturze staropolskiej, Toruń 1994. Na temat przyczyn sporadycznego występowania konwencji utopijnej w dawnej literaturze polskiej zob. T. Kostkiewiczowa, Polski wiek światet, dz. cyt., s. 222.

${ }^{21}$ Utwór Krasickiego porównywali z Żywotem cztowieka poczciwego Reja między innymi: J. Kleiner, O Krasickim i Fredrze: dziesięć rozpraw, Wrocław 1956, s. 77 oraz T. Kostkiewiczowa, Studia o Krasickim, dz. cyt., s. 114.

${ }^{22}$ E. Cassirer, dz. cyt., s. 87. 
zwierzchności nad nim; wszyscy są równi. Skoro zaś są złączeni w towarzystwo, natenczas toż samo towarzystwo, pozwala dla dobra swojego w niektórych okolicznościach niejakiej nad szczególnymi - albo zgromadzeniu, albo niektórym z zgromadzenia - zwierzchności ${ }^{23}$.

Mędrzec wykłada bohaterowi w prostych słowach także stosunek Nipuan do Stwórcy: „Bóg jest źródłem wszystkiej istności; Bóg jest początkiem wszystkiego dobra; Bóg być powinien jednym celem i końcem wszystkich spraw naszych" 24 .

Jak zauważył Józef Tomasz Pokrzywniak, religia mieszkańców wyspy Nipu ma charakter oczywisty i niepodważalny ${ }^{25}$. Wiara w „Najwyższą Istność” wynika więc z determinującego wszystkie aspekty egzystencji ludzi porządku naturalnego. Mieszkańcy wyspy są z natury religijni, wierzą w jednego Boga, a zarazem świadomie separują się od świata zewnętrznego, budując autarkiczną rzeczywistość opartą na wspólnych wartościach, do których należą common sense, poczucie współodpowiedzialności za całą społeczność i ochrona tradycji. Jak nietrudno zauważyć, aksjologia owego utopijnego systemu pełni funkcję zwierciadła, w którym odbijają się wszystkie negatywne cechy realnego systemu społecznego zarówno Rzeczypospolitej, jak i innych państw, w których owe konserwatywne, oparte na tradycji ziemiańskiej wartości uległy atrofii. Krasicki, idąc tropem Rousseau, obnaża główne wady systemu oświeceniowego: począwszy od scjentyzmu i intelektualizmu, któremu przeciwstawia zdrowy rozsądek prostego człowieka, skończywszy zaś na krytyce postępu, który wykorzenia dawne przekonania wspólnoty, pozbawiając jednostkę dumy z własnego pochodzenia. Warunkiem szczęśliwego życia w społeczeństwie czyni Krasicki zgodne podejście do wartości, które, mimo że w wypadku Nipu okazują się konserwatywne, zostały zbudowane na fundamentach nowatorskiej propozycji Rousseau opartej na owym jednostkowym pragnieniu stworzenia idealnej wspólnoty. Jedynie powszechna zgoda co do sposobu życia grupy jest bowiem podstawą, a także warunkiem istnienia systemu społeczno-politycznego Nipuan. Jak jednak przekonuje się czytelnik Mikotaja Doświadczyńskiego przypadków, ów rodzaj społecznej idylli dla głównego bohatera ma charakter przytłaczający i w końcu w tajemnicy przed autochtonami ucieka on z Nipu.

Zarówno prawo, jak i religia okazują się przy tym konstruktami charakterystycznie oświeceniowymi - a więc uniwersalnymi i abstrakcyjnymi, i jako takie pierwotnymi względem wszelkich realnych instytucji normatywnych i religijnych. Według Hugo Grotiusa, teoretyka prawa, którego myśl znacząco

${ }^{23}$ I. Krasicki, Mikotaja Doświadczyńskiego przypadki, dz. cyt., s. 114.

24 Tamże, s. 119.

25 J.T. Pokrzywniak, Treści religijne w twórczości Ignacego Krasickiego [w:] Motywy religijne w twórczości pisarzy polskiego oświecenia, red. T. Kostkiewiczowa, Lublin 1995, s. 152. 
wpłynęła na idee Oświecenia, prawo naturalne niczym arytmetyka stanowi abstrakcyjny system niezależny od istnienia podmiotu ${ }^{26}$. To właśnie oświeceniowa idea prawa - niezmiennego, uniwersalnego i niezależnego od poszczególnych jednostek - umożliwia Krasickiemu zbudowanie racjonalnej wspólnoty, gwarantującej mieszkańcom trwały porządek i bezpieczeństwo, z dala od krańców „cywilizowanej” Europy. Warunkiem sine qua non owego idealnego życia okazuje się wręcz świadomy izolacjonizm, zapobiegający przepływowi zewnętrznych, obcych Nipuanom idei.

W świetle dialogu polemicznego Krasickiego z tezami Rousseau nie zaskakuje nas, że autor, tworząc w Mikotaja Doświadczyńskiego przypadkach społeczeństwo utopijne, za istotne uważa również przytoczenie tak „mrocznego" elementu jego historii, jak opowieść o nieposłuszeństwie obywatela, którego za złamanie tabu w barbarzyński sposób ukarano śmiercią. Konwencjonalny dydaktyzm utopii Krasickiego zabarwiony jest niepokojącym realizmem - okazuje się bowiem, że obrona wartości wspólnotowych wymaga poświęcenia życia jednostek. To szokujące zachowanie Nipuan, spowodowane chęcią utrzymania za wszelką cenę status quo na wyspie, nie pozwala, jak chce Józef Tomasz Pokrzywniak, potraktować Mikotaja Doświadczyńskiego przypadków jako powieści prezentującej ucieleśnione idee ${ }^{27}$. Racjonalność bowiem w projekcji literackiej Krasickiego, co zauważają także w swych późniejszych o prawie dwieście lat obserwacjach przedstawiciele szkoły frankfurckiej, krytycznej wobec epoki oświecenia, nie wyklucza wykalkulowanej zbrodni tym samym jednak niemożliwą do zrealizowania ideą utopijną pozostaje świat bez przemocy ${ }^{28}$. Okazuje się ona nieunikniona także w społeczeństwie skonstruowanym pod egidą wzniosłych idei równości czy sprawiedliwości, w społeczeństwie zbudowanym na fundamencie naturalnych pragnień jednostek. Spostrzeżenie to stanowi zarazem argument na rzecz kontrowersyjnej oceny Pierre’a Chaunu, twierdzącego, że spopularyzowana przez Rousseau konwencja utopii to w oświeceniu wentyl bezpieczeństwa dla obskurantów, którzy w tego typu konstrukcjach dawali upust eskapistycznej potrzebie ucieczki ze świata bezwzględnie ciążącego ku przyszłości ${ }^{29}$.

Krasicki jednak niewątpliwie obskurantem nie był, ukazując w kreacji literackiej Nipu, że idea społeczeństwa z kart Umowy spotecznej stanowi swego rodzaju projekcję zastępczą wyobraźni, napędzaną pragnieniem stworzenia lepszej rzeczywistości. W takim ujęciu koncepcje Rousseau, twórcy oświeceniowej utopii stanu natury, podobnie jak jego program wychowania, zaprezentowany

${ }^{26}$ Tamże, s. 217.

27 J.T. Pokrzywniak, Ignacy Krasicki, Poznań 1995, s. 20-22.

${ }^{28}$ Jak zauważył Northop Frye, rozwój kulturowy charakteryzuje się większą agregacją jednostek w nowym systemie - jest to podstawowy postulat kultur rozwiniętych, dążących do stworzenia spójnej wizji świata, w którym nie ma miejsca na wykluczenie społeczne (w tym także na przemoc). Zob. N. Frye, Anatomia krytyki, tłum. M. Bokiniec, Gdańsk 2012, s. 390.

29 P. Chaunu, dz. cyt., s. 150. 
w Emilu, stanowią łabędzi śpiew wyidealizowanej wersji przeszłości, mającej stanowić podstawę do budowy jeszcze lepszej przyszłości. Sprzeciw wobec rzeczywistości, która ukształtowała młodego Doświadczyńskiego, wyrażany przez Krasickiego za pomocą satyry i ironii w powieści, może zostać zinterpretowany - mimo zapewne odmiennej intencji samego autora - w ten sam sposób. Można bowiem pokusić się o twierdzenie, że oświeceniowa utopia to nic innego jak świat oparty na pragnieniu stworzenia rzeczywistości przyjaznej dla wszystkich ludzi (zarazem to utopia zgodna z oświeceniową koncepcją umowy społecznej, a więc kreowania otoczenia $\mathrm{z}$ uwzględnieniem wspólnej woli obywateli). Z jednej więc strony utopia potwierdza oświeceniowy mit o możliwości budowy nowego świata, z drugiej zaś strony daje sposobność ucieczki od racjonalności w stronę dziecięcego marzenia. Toteż postęp oświecenia niewątpliwie przyczyniał się do wzmożenia ruchów konserwatywnych, niechcących rozstać się z negowaną przez nie wizją rzeczywistości. One również należą do tej epoki i nie ograniczają się jedynie do reakcyjnego dorobku państw zacofanych względem oświeceniowego centrum. Mimo powodowanej impulsem ucieczki z wyspy, po pełnej przykrych przygód podróży powrotnej do Rzeczypospolitej Doświadczyński stara się część idei Nipuan (będących, jak pamiętamy, ilustracją stanu natury Rousseau) wcielić w nowe życie odpowiedzialnego ziemianina:

Najprzód ażebym miał w świeżej zawżdy pamięci szczęśliwość obywatelów Nipu i święte mistrza mojego Xaoo nauki, niedaleko rezydencji mojej wystawić kazałem dom zupełnie podobny do owego, gdzie Xaoo mieszkał. Sad, rzeczka, sadzawka, pole, w tychże wszystko co tam rozmiarach - słodkie mi czyniło omamienie. Ile razy tam jestem, pasę myśl moją przypomnieniem zbawiennych tamtejszych rodzajów i maksym ${ }^{30}$.

Bohater Krasickiego po powrocie z utopijnej wyspy próbuje w ten sposób symbolicznie zbudować lokalną kontrpropozycję dla oświeceniowej rzeczywistości postępu, której dynamika z czasem doprowadziła do rekonfiguracji ról społecznych i technicyzacji Europy Zachodniej. Autor Mikotaja Doświadczyńskiego przypadków mimo dość czytelnej w powieści krytyki teorii społecznej Rousseau, a przede wszystkim jego wyidealizowanego pojęcia moralności, pozwala swemu bohaterowi na przejęcie sentymentalnej estetyki utopii, która stanowi istotny element wyobraźni filozofa z Genewy ${ }^{31}$.

${ }^{30}$ I. Krasicki, Mikotaja Doświadczyńskiego przypadki, dz. cyt., s. 177.

${ }^{31}$ Przykładem sentymentalnego ukształtowania utopijnego otoczenia jest miejscowość Clarens z kart Nowej Heloizy, która to powieść Rousseau - co znamienne - była wówczas nazywana „Biblią zakochanych”. Z romansów francuskich Krasicki drwi w pierwszej części Doświadczyńskiego, choć sam - mimo krytyki tego typu lektur - stosuje typowe dla owego romansu chwyty (np. rozłąka Mikołaja i Julianny oraz nieoczekiwane, przypadkowe spotkanie bohaterów po latach). Zob. tamże, s. 192. 
Stworzenie własnej, idealnej wyspy w niedoskonałej rzeczywistości nie jest oczywiście jedynie kwestią wyglądu najbliższego otoczenia. W literackim świecie Krasickiego główni bohaterowie zawsze są ludźmi wierzącymi i to wiara, oprócz przyrodzonego rozumu, staje się głównym elementem regulującym ich zachowania ${ }^{32}$. Wiara ta, wypływając $\mathrm{z}$ rozumu naturalnego, ma charakter pierwotny, dzięki czemu nie zagraża ona szczęściu i bezpieczeństwu obywateli wyspy. Jakimi jednak narzędziami obrony przed zagrażającą jej kulturą bezwzględnego progresu dysponuje religia, której wyznawcą był sam Krasicki? Brak możliwości przestrzennej izolacji, powszechna, oświeceniowa krytyka „religii pozytywnych”, rozwój deizmu i nauki trwale przekształcającej obraz wszechświata zagrażają wszak dawnym, religijnym autorytetom. Ratunkiem dla zachowania tradycyjnych wartości staje się próba wplecenia systemu religijnego w samą naturę. Krasicki czyni zatem to, co wcześniej proponował już Gottfried Wilhelm Leibniz, umieszczający swoje monady w nieskończonym, newtonowskim uniwersum, łącząc więc tym samym osiągnięcia naukowe z wiarą w Boga. Autor Mikotaja Doświadczyńskiego przypadków jest człowiekiem świadomym konfliktu wartości wynikającego ze starcia nauki (coraz częściej przekształcającej się w technikę) z tradycją zakorzenioną w aksjologii religijno-konserwatywnej.

Krasicki mimo wykorzystania w Mikotaja Doświadczyńskiego przypadkach niektórych elementów teorii społecznej Rousseau nieustannie podkreśla cenę, jaką przyszłoby zapłacić za życie w świecie utopii - jego autarkia jest możliwa jedynie w miejscu oddalonym od rzeczywistego świata konfliktu, na wyobrażonej wyspie lub na kartach idealistycznego traktatu. Nipu pozostaje więc przestrzenią odgrodzoną od zagrażającej jej rzeczywistości historyczno-geograficznej oceanem, nieprzyjaznym wszystkim, którzy znaleźli się w pobliżu wyspy. Pełna niebezpieczeństw przestrzeń morska staje się jednym z gwarantów utrzymania porządku w świecie mieszkańców wyspy, będąc trudną do przekroczenia barierą zarówno dla osób z zewnątrz (obcych aksjologicznie wyspiarzom), jak i dla tych, którzy decydują się na ucieczkę („zdrajców” systemu społecznego utopii). W wypadku realiów Rzeczypospolitej warunki te oczywiście byłyby niemożliwe do spełnienia, podobnie jak warunek utrzymania powszechnego porządku i całkowitej kontroli grupy nad własnymi obywatelami.

Literacka fantazja Krasickiego o powszechnej zgodzie, będąca rezultatem umowy społecznej mieszkańców wyspy, zainspirowana pismami Rousseau, w kraju politycznej anarchii, który stanowiła Rzeczypospolita doby osiemnastego wieku, jest głosem w dyskusji na temat coraz szybszych zmian

32 „Po chrześcijańsku” myśli Doświadczyński tuż po katastrofie statku, a więc jeszcze przed zetknięciem się z moralnością Nipuan. Pokrzywniak zauważa jednak, że konwencja Doświadczyńskiego nie pozwoliła Krasickiemu na pełną eksplikację znaczenia religii w życiu jednostki miejsce religii w życiu człowieka w pełni ukazuje dopiero następna powieść Krasickiego Pan Podstoli. Zob. J.T. Pokrzywniak, Treści religijne w twórczości Ignacego Krasickiego, dz. cyt., s. 125. 
społecznych i możliwych zabezpieczeń przed zagrożeniem ze strony obcych. Zarówno Rousseau, jak i Krasicki, mimo ponadprzeciętnej świadomości społecznej, poruszają się jednak tylko w obrębie literatury i poprzestają na snuciu wyobrażonych utopii, przedstawiając w niej jedynie wytyczne i zalecenia pozwalające zbudować lepszy świat. Polemika Krasickiego z możliwością całkowitego zastosowania utopii społecznej projektu Rousseau, obecna w powieści o Doświadczyńskim, zwraca naszą uwagę w kierunku elementu biografii łączącego Biskupa Warmińskiego i autora Umowy spotecznej. Obaj nie mogli się odnaleźć w realiach politycznych własnych państw: Krasicki krytykuje samowolę szlachty, a Rousseau absolutystyczną Francję ${ }^{33}$.

Jednocześnie świadectwa podróżnicze ówczesnych odkrywców obcych krain i kultur nie pozostawiają złudzeń, w jaki stopniu projekcja lepszego świata poza krytykowaną za zepsucie obyczajów Europą była zgodna z prawdą: „nie można zorganizować społeczeństwa z człowiekiem w stanie naturalnym, gdyż jest on barbarzyński, zły i podstępny (...), człowiek z natury nie jest dobry ani tu, ani tam"34.

Ekspedycje geograficzne, przyczyniające się do rozkwitu Oświecenia, zarazem podważają więc jego główne, filozoficzne idee. Okazuje się bowiem, że obowiązująca wówczas koncepcja powszechnej, ludzkiej natury, która pierwotnie była lepsza niż obecnie, stanowi jedynie hipotezę coraz bardziej chwiejącą się w swych podstawach ${ }^{35}$. Wyspa Nipu jest przez samego Krasickiego miejscem potraktowanym w sposób ambiwalentny - jej kreacja wskazuje zarazem na sentyment autora do społeczeństwa uporządkowanego (reprezentowanego przez Nipuan), ale Krasicki (czego nie czyni Rousseau) zdaje sobie sprawę z konieczności ograniczenia swobód, które przeszkadzałyby w stworzeniu społeczeństwa karnego, podporządkowanego wymogom dobrego państwa. Model utopijny Rousseau wraz z jego koncepcją wolności jako fundamentu każdej umowy społecznej ${ }^{36}$ kłóci się z sarmackim wyobrażeniem wolności prywatnej, która zakłada możliwość liberum veto. Wydaje się, że brak przestrzeni do realizacji owej „złotej wolności” jednostki jest główną przyczyną ucieczki Doświadczyńskiego.

Nieoczywistość utopijnego świata Mikotaja Doświadczyńskiego przypadków nie kończy się na przeprowadzonej tu charakterystyce świata Nipu. Okazuje się bowiem, że podróż bohatera na wyspę, mimo że początkowo wymuszona i zupełnie przypadkowa, gdyż podyktowana ucieczką przed wierzycielami, stanowi zarazem konieczny warunek jego rozwoju. Krasicki wprowadza zatem pewne novum do staropolskiej tradycji „człowieka poczciwego”.

${ }^{33}$ Zob. A.W. Lipatow, dz. cyt., s. 69.

${ }^{34}$ Cyt. za: M.N. Bourguet, Odkrywca [w:] Cztowiek oświecenia, red. M. Vovelle, tłum.

M. Gurgul i in., Warszawa 2001, s. 304.

35 E. Cassirer, dz. cyt., s. 164.

${ }^{36}$ Zob. J.J. Rousseau, dz. cyt., s. 52-54. 
Autorowi powieści nie wystarczy jedynie doświadczenie zdobyte w ramach edukacji ziemiańskiej, postuluje on poszerzenie ogólnej edukacji o podróże do obcych krajów (nawet jeśli Krasicki pisze niekiedy coś zupełnie innego) ${ }^{37}$. W ostatecznym rozrachunku okazuje się bowiem, że doświadczenie uzyskane podczas podróżowania sprawia, iż jednostka staje się bardziej krytyczna w stosunku do kolejnych, naukowych nowości stworzonych przez epokę świateł. Racjonalizm zaprezentowany w tekstach Krasickiego jest także narzędziem intelektualnej analizy odmiennych kulturowo wzorców. Wyjaśnia to działanie Mikołaja, bohatera powieści, który po przebytych doświadczeniach uważniej analizuje pochodzące ze świata zewnętrznego informacje, a rezultatem tej ostrożności jest próba dokonania reform na terenie własnego kraju. Albowiem kontinuum powieści-traktatu dydaktycznego zastosowane przez Krasickiego również $w$ Panu Podstolim pozwala na wysnucie tezy, że motorem pozytywnych zmian jest owo doświadczenie wynikające ze znajomości ludzkiej natury. Obaj bohaterowie, kierując się przede wszystkim oświeceniowym rozumem, próbują zaszczepić pozytywne elementy struktury społecznej Nipu na gruncie własnej rzeczywistości gospodarczo-politycznej, by ulepszyć rzeczywistość Sarmatów. Aksjologia oparta na umowie społecznej respektującej równość wszystkich jednostek jest zdeterminowana etyką obowiązku wobec pozostałych współobywateli oraz samej ojczyzny. Biskup Warmiński postępuje tu zgodnie z zaleceniami Rousseau. Konstatacja ta jest istotna, ponieważ reforma, którą proponuje Krasicki, mimo że zainspirowana obcą rzeczywistością (a tak naprawdę stanowiąca selekcję zachodnich idei oświeceniowej państwowości), nie godzi w dawno już ukształtowany, szlachecki świat. Krasicki zręcznie lawiruje więc między dobrem jednostki a dobrem społecznym, znajdując złoty środek w pracy u podstaw - poczucie obowiązku, które cechuje cnotliwego obywatela, zapewnia społeczeństwu wsparcie ze strony każdej jednostki, jednocześnie jednak podmiot ma zagwarantowaną względną autonomię działania: poza nim samym nikt nie sprawuje nad nim pełni kontroli (inaczej niż w przypadku Nipuan). Okazuje się bowiem, że gospodarstwo Pana Podstolego jest mikropaństwem zarządzanym przez rozumnego władcę, organizującego zarazem rzeczywistość swych poddanych.

Utopia Nipu, która w zamierzeniu miała stanowić polemikę z obcym ideologicznie systemem światopoglądowym, w rzeczywistości częściowo system ten adaptuje (przede wszystkim za sprawą dialogu z koncepcją umowy społecznej Rousseau). Krasicki jedynie modyfikuje sens wykorzystywanych przez oświeceniowców pojęć: rozum naturalny utożsamia on nie tyle $\mathrm{z}$ abstrakcyjnym

${ }^{37}$ Jak na przykład w satyrze Podróż lub w liście poetyckim Podróż Pańska. Zob. I. Krasicki, Podróż, Podróż Pańska [w:] tegoż, Satyry i listy, Wrocław 1988. Krytyka podróży w ujęciu Krasickiego jest przedmiotem mojego artykułu: Podróż niesentymentalna. Ignacego Krasickiego dyskusja ze Sternéowskim ideatem podróży [w:] Topografie podróży, red. K. Olkusz, Kraków 2018 (tekst w druku). 
narzędziem analitycznym, ile z konkretnym przejawem zdrowego rozsądku, a rzeczywistość „powszechnej zgody” zostaje w świecie utopii zabezpieczona przez system kar dla każdego, kto z tej „dobrowolnej” umowy chciałby się wyłamać. Tym samym koncepcja autora Mikotaja Doświadczyńskiego przypadków uzyskuje oryginalny i zarazem regionalny kształt, choć stworzona jest $\mathrm{z}$ tego samego, emocjonalnego materiału, z którego utkano obraz oświecenia europejskiego. Krasicki pokazuje, że nawet w literackim świecie utopii nie są możliwe całkowita harmonia społeczna i pełne zintegrowanie systemu wartości.

\section{Bibliografia}

Baczko B., Światta utopii, tłum. W. Dłuski, Warszawa 2016.

Bourguet M.N., Odkrywca [w:] Cztowiek oświecenia, red. M. Vovelle, tłum. M. Gurgul i in., Warszawa 2001.

Cassirer E., Filozofia oświecenia, tłum. T. Zatorski, Warszawa 2010.

Chaunu P., Cywilizacja wieku oświecenia, tłum. E. Bąkowska, Warszawa 1989.

Frye N., Anatomia krytyki, tłum. M. Bokiniec, Gdańsk 2012.

Graciotti S., Utopia w dzietach Ignacego Krasickiego, „Przegląd Humanistyczny” 1972, t. 16, nr 4.

Juszczyk A., Stary, wspaniaty świat. O utopiach pozytywnych i negatywnych, Kraków 2014.

Kleiner J., O Krasickim i Fredrze: dziesięć rozpraw, Wrocław 1956.

Kostkiewiczowa T., Polski wiek światet. Obszary swoistości, Wrocław 2002.

Kostkiewiczowa T., Studia o Krasickim, Warszawa 1997.

Krasicki I., Mikotaja Doświadczyńskiego przypadki, oprac. M. Klimowicz, Wrocław 1975.

Krasicki I., Podróż, Podróż Pańska [w:] tegoż, Satyry i listy, Wrocław 1988.

Krzewińska A., Początki utopii w literaturze staropolskiej, Toruń 1994.

Lipatow A.W., Rousseau i Krasicki: utopia i antyutopia w „Mikotaja Doświadczyńskiego przypadkach”, ttum. Z. Smolska „Pamiętnik Literacki” 1980, z. 2.

Pateman C., Kontrakt ptci, tłum. J. Mikos, Warszawa 2014.

Pokrzywniak J.T., Ignacy Krasicki, Poznań 1995.

Pokrzywniak J.T., Treści religijne w twórczości Ignacego Krasickiego [w:] Motywy religijne $w$ twórczości pisarzy polskiego oświecenia, red. T. Kostkiewiczowa, Lublin 1995.

Rousseau J.J., Umowa spoteczna, tłum. A. Peretiatkowicz, Kęty 2009.

Wołoszyński R., Ignacy Krasicki: utopia i rzeczywistość, Studia z zakresu Oświecenia, t. 11, Wrocław 1970.

Żukowska K., Podróż niesentymentalna. Ignacego Krasickiego dyskusja ze Sterne’owskim ideatem podróży [w:] Topografie podróży, red. K. Olkusz, Kraków 2018 (tekst $\mathrm{w}$ druku). 